\title{
The effect of isolated Bacillus ureolytic bacteria in improving the bio-healing of concrete cracks
}

\author{
Gehad Mokhtar ${ }^{1}$, Ahmed Abd-El-Azim Ahmed ${ }^{1}$ and Amany M. Reyad ${ }^{2}$ (D)
}

\begin{abstract}
Background: Reinforcement corrosion and the concrete strength reduction are critical problems that resulted from crack creation in concrete. Very expensive and hazardous technologies based on chemical materials have been provided for repairing the cracks. Recently, crack repair using bio-catalysis precipitating bacteria has been developed as a viable and ecofriendly alternative technique. The main target of this study was to select and identify bacterial isolates with high urease activity to use in filling the cracks by the precipitation of $\mathrm{CaCO}_{3}$.

Results: Two endospore-forming and alkali-resistant ureolytic bacteria were combined with concrete to tolerate the mechanical stresses generated by mixing. The two isolates designated as (B1 and B2) were selected and identified as Bacillus wiedmannii strain FSL W8-0169 and Bacillus paramycoides strain MCCC 1A04098, respectively, using 16SrDNA gene sequencing. Both bacterial species completely heal cracks in fully destructed concrete and significant enhancement in compressive strength was illustrated. The calcite filling of cracks and $\mathrm{CaCO}_{3}$ crystals that were screened using a scanning electron microscope may explain the crack healing and the enhancement in concrete strength.
\end{abstract}

Conclusions: Bacillus wiedmannii strain FSL W8-0169 and Bacillus paramycoides strain MCCC 1A04098 can be inserted with the concrete to improve the compressive strength and the self-healing of cracks. The two ureolytic bacterial strains can be used to protect water buildings from exposure to frequent cracks.

Keywords: Ureolytic activity, Bacillus, Bio-concrete, Compressive strength, Crack healing

\section{Background}

The creation of cracks in concrete is highly undesirable as it provides an open pathway for the water ingress leading to reinforcement corrosion and the concrete strength reduction. Various methods have been provided for repairing the cracks based on chemical materials that are very expensive and hazardous to environment [1]. Recently, crack repair using bio-catalysis precipitating bacteria has been developed as a viable alternative. This bacterial curing technique is preferable over other technologies as it is ecofriendly, bio-based, durable, and

\footnotetext{
*Correspondence: amr01@fayoum.edu.eg

${ }^{2}$ Botany Department, Faculty of Science, Fayoum University, Fayoum, Egypt

Full list of author information is available at the end of the article
}

cost-effective [2]. Urease-positive bacteria affect $\mathrm{CaCO}_{3}$ precipitation (calcite) by producing an enzyme called urease. This enzyme converts urea to $\mathrm{CO}_{2}$ and ammonia, leading to a rise in $\mathrm{pH}$ and $\mathrm{CaCO}_{3}$ precipitation in the bacterial environment [3]. The precipitation of calcite was promoted by bacteria as Bacillus sp was found to be effective in concrete crack healing and increasing the concrete and mortar compressive strength [4]. In various studies, it has been shown that adding specific bacterial species to cement-sand concrete or mortar causes calcite deposition within matrix pores, allowing it to be used as a filling material to repair cracks in concrete structures [5]. It was also noticed that the mixing of bacterial spores or cells with growth medium, consisting of $20 \mathrm{~g} / \mathrm{l}$ urea and $25 \mathrm{Mm}$ calcium chloride with the concrete could increase the strength of the material by $20-35 \%$ 
compared to control $[6,7]$. Castanier et al. [8] showed that many factors influence microbial-induced $\mathrm{CaCO}_{3}$ precipitation (MICP), including (a) the $\mathrm{pH}$ of the atmosphere, (b) carbonate concentration, (c) the presence of nucleation sites, and (d) calcium concentration. Because of the widespread existence of ureolytic bacteria, MICP by ureolytic activity has been used in several studies [9, 10]. Due to the fact that it is easy to control and generates large quantities of carbonate in a short period of time, urea hydrolysis is the most powerful of the calcitegenerating reactions. Moreover, it does not only maintain an alkaline $\mathrm{pH}$, but it also produces a plentiful supply of calcite by providing bio-based minerals [11].

The current research focuses on isolating and identifying endospore-forming, calcite-precipitating, and ureasepositive bacteria, as well as determining their suitability for use in concrete. The impact of bacteria on compressive strength and crack healing has also been studied EDX-SEM was used to visually inspect and quantify the calcite precipitation. For the first time, we detected the stalactite deposits in cracks after 90 days water curing of bacterial concrete specimens.

\section{Methods}

\subsection{Bacterial isolation}

With minor modifications, the method defined by Ishaka et al. [12] was used. From the Sewage Water Treatment Company, Fayoum, Egypt, a sample was collected from the active sludge. Ten milliliters from the sample was diluted in $100 \mathrm{~mL}$ sterilized distilled water. Fifty microliters from the diluted mixture was inoculated in Petri dishes of the previously sterilized alkaline nutrient agar (ANA). ANA was prepared by adding $\mathrm{NaOH}$ solution droplets till reaching $\mathrm{pH}$ 14. Incubation for $36 \mathrm{~h}$ at $30^{\circ} \mathrm{C}$ was performed and the alkali-tolerant bacterial species that could grow were purified and preserved at -80 for further tests.

\subsection{Urease activity assay (was detected using two methods)}

Method one: Seven alkali-tolerant bacterial isolates were inoculated into urea broth and incubated at $30{ }^{\circ} \mathrm{C}$ for $24 \mathrm{~h}$. A pink color was produced with bacteria that rapidly hydrolyze urea using Phenol red as indicator [13].

Method two: The electric conductivity approach was used as Omoregie et al. [14] for the bacterial isolates that rapidly hydrolyze urea. The urease reaction involved the hydrolysis of the non-ionic substrate urea to ionic compounds, resulting in a proportionate increase in conductivity under normal conditions. Urea-nutrient broth was used for bacterial culturing. One millimeter of bacterial broth culture was mixed with $9.0 \mathrm{~mL}$ of $1 \mathrm{M}$ urea solution. By electric conductivity meter, the conductivity was recorded after $0,10,60$, and $100 \mathrm{~min}$ of incubation at $25{ }^{\circ} \mathrm{C}$. The rate of increase in conductivity, measured in $\mathrm{mS} / \mathrm{m}$.

\section{3 $\mathrm{CaCo}_{3}$ (calcium carbonate) precipitation}

For the measurement of $\mathrm{CaCO}_{3}$ precipitation, a method showed by Krishnapriya et al. [1] was followed. Thirty millimeters of NB-U/Ca (Nutrient broth implemented with $2 \%$ urea and $\mathrm{CaCl}_{2}$ ) was injected with $2 \%$ bacterial inoculum then incubated in shaking incubator (130 rpm) for 7 days at $30^{\circ} \mathrm{C}$. Using a Whatman filter paper, precipitated $\mathrm{CaCO}_{3}$ was filtered and dried in an oven of $55^{\circ} \mathrm{C}$ for $8 \mathrm{~h}$ and then weighed. From the following equation, weight of precipitated $\mathrm{CaCO}_{3}\left(\mathrm{~W}_{\mathrm{c}}\right)$ was calculated.

$$
\mathrm{Wc}=\mathrm{Wfc}-\mathrm{Wf}
$$

where (Wf) is the empty filter paper weight and Wfc is the weight of filter paper containing $\mathrm{CaCO}_{3}$ precipitant.

\subsection{Endospore staining}

By Schaeffer-Fulton endospore staining procedure as per Hussey [15], the ability to synthesize endospores was determined in the selected bacterial isolates. Heat-fixed bacterial isolate smears were prepared. The smears were then immersed with malachite green after being coated with absorbent paper. Steam started to rise from the slide surface as they were heated. Drops of malachite green were supplied on the paper as it started to dry to maintain it moist. Using tweezers, the paper was taken away from the slide, and then washed thoroughly under running water. The slide was drained, counterstained, polished, and tested under a light microscope $(100 \mathrm{x})$ after being incubated for $60 \mathrm{~s}$ with 0.5 percent safranin stain. The endospores are green and the vegetative cells are red or pink.

\subsection{Molecular identification}

For the molecular identification, the genomic DNA has been extracted using standard bacterial procedures described by Molecular Cloning [16]. The PCR blend was prepared as follow: $10 \mu \mathrm{L}$ (10x) PCR buffer, $3 \mu \mathrm{L}(50 \mathrm{mM})$ $\mathrm{MgCl}_{2}, 1 \mu \mathrm{L}(20 \mathrm{pmol} / \mu \mathrm{L})$ of each primer, $1 \mu \mathrm{L}(10 \mathrm{mM})$ Mixture of dNTPs, $0.5 \mu \mathrm{L}(2.5 \mathrm{U})$ Taq polymerase, $2 \mu \mathrm{L}$ gross DNA extract, and volume completed by sterilized distilled $\mathrm{H}_{2} \mathrm{O}$ to $100 \mu \mathrm{L}$. Under the conditions set out below, PCR was performed for 35 cycles: denaturation stage at $90-94{ }^{\circ} \mathrm{C}$ for $40 \mathrm{~s}$, the annealing step was controlled for $1 \mathrm{~min}$ at $55^{\circ} \mathrm{C}$, for the extension step, $72{ }^{\circ} \mathrm{C}$ for $2 \mathrm{~min}$ was adjusted, and the final expansion for $10 \mathrm{~min}$ at $72{ }^{\circ} \mathrm{C} .10 \mu \mathrm{L}$ from the products of PCR was added to $2 \mu \mathrm{L}$ of DNA the gel containing $0.5 \mu \mathrm{g} / \mathrm{mL}$ ethidium bromide in the Tris-Borate-EDTA (TBE) buffer is then visualized using a UV transilluminator by the buffer loading 
and electrophoresis analysis on $0.7 \%$ horizontal agarose (60 $\mathrm{min}$ at $15 \mathrm{~V} / \mathrm{cm}$,). The sequencing of the amplified fragments was completed at GATC Biotech, Constance, Germany. DNA sequences were aligned at NCBI Data Base (www.ncbi.nlm.nlh.gov). The phylogenetic trees were established using a neighbor-joining technique using TREEVIEW software (1.6.6) derived from gene sequences of $16 \mathrm{~S}$ rDNA of some phylogenetic close strains to the isolated strain. The sequences had accession numbers by their submission in GenBank NCBI database.

\subsection{Bio-healing agent preparation}

Bacterial cultures were prepared in alkaline nutrient broth. Turbidity was conducted under spectrophotometric conditions giving optical density (OD) 0.6 at $600 \mathrm{~nm}$. For the bacterial spore harvest, several times of centrifugation in dual sterilized tap water were made after heating the bacterial cultures for $35 \mathrm{~min}$ at $80{ }^{\circ} \mathrm{C}$ to inactivate bacterial vegetative cells and obtain a high number of spores. The bacterial spores were adjusted to be $1.39 \times 10^{7} \mathrm{cells} / \mathrm{cm}^{3}$ of the total concrete mixture, in sterilized tap water for preparing the bio-based concrete, the nutrients, including $2 \mathrm{~g} / \mathrm{L}$ yeast extract, $40 \mathrm{~g} / \mathrm{L}$ calcium chloride anhydrous, and $65 \mathrm{~g} / \mathrm{L}$ urea were dissolved.

\subsection{Experimental design}

Following Egyptian Code Practice (ECP) and American Society for Testing and Materials (ASTM) standards, the bio-based agent was added in the final step of concrete constituents mixing. Control concrete specimens (C) were prepared using all medium nutrients except spores, $\mathrm{B} 1$ was inoculated by bacterial spores of $B$. wiedmannii, and $\mathrm{B} 2$ was inoculated by bacterial spores of $B$. paramycoides. Concrete mixture design is illustrated in Table 1. Immediately after mixing, the test concrete specimens were cast. After $24 \mathrm{~h}$, the specimens were removed from the molds, treated in water for 28 days, and then checked for compressive strength. To conduct the test, a $2000 \mathrm{KN}$ (ADR 2000) compression testing system was used. Following the ISO 4012 standard requirements, specimens were positioned on a rigid bottom bearing block with a spherical bearing block attached to the compressive testing unit. The compression load was applied to the specimen at a rate of $0.6 \mathrm{~N} / \mathrm{mm}^{2}$ per second, which was within the ECP's specified range. The max compressive strength $(\sigma)$ was calculated by the division of the peak load $(P)$ by the cross-sectional area $(A)$ of each specimen. The compressive strength was examined at 7,14 , and 28 days and calculated using the following formula (average for three cubes).

$$
\sigma=\frac{P}{A}
$$

\subsection{SEM calcite precipitates characterization}

Full destruction was applied on concrete beams for cracks creation. For a total of 90 days, the beams were submerged in water. After 28 and 90 days period, photographs were taken for detecting calcite appearance in cracks. The calcite precipitation by bacterial isolates in the cracks of concrete specimens was screened and quantified using EDX-SEM analysis. EDX-SEM analysis was obtained using a Carl Zeiss sigma 500 VP Jeol JSM 6390 apparatus.

\subsection{Statistical analysis}

Data were statistically analyzed using a two-way analysis of variance (ANOVA test) using SPSS Statistical Package Program [17] version 23. Mean of treatments was compared by Duncan multiple range test when the differences were significant [18]. Level of significance in all tests was $P \leq 0.05$. The results are expressed as means \pm standard error (SE).

\section{Results}

\subsection{Isolation endospore-forming and alkali-tolerant bacteria}

From the isolation step, seven bacterial isolates could tolerate till $\mathrm{pH}$ 14. All isolates are gram negative and endospore-forming (see Additional file 1: Figure S1). Figure 1 shows the green color of $\mathrm{B} 1$ and $\mathrm{B} 2$ endospores as dark black colored spherical dots and the vegetative cells seem light colored rods.

Table 1 The mixture design of the concrete specimens

\begin{tabular}{|c|c|c|c|c|c|}
\hline $\begin{array}{l}\text { Type of } \\
\text { concrete }\end{array}$ & Water $\left(\mathrm{kg} / \mathrm{m}^{3}\right)$ & $\begin{array}{l}\text { Cement (kg/ } \\
\left.\mathrm{m}^{3}\right)\end{array}$ & Sand $\left(k g / m^{3}\right)$ & $\begin{array}{l}\text { Aggregate (kg/ } \\
\text { m3) }\end{array}$ & Bio-supplements \\
\hline C & 150.8 & 350 & 675.5 & 1340.2 & With nutrients and without bacterial spores \\
\hline B1 & 150.8 & 350 & 675.5 & 1340.2 & With nutrients and B1 bacterial spores \\
\hline B2 & 150.8 & 350 & 675.5 & 1340.2 & With nutrients and B2 bacterial spores \\
\hline
\end{tabular}

C, With nutrients and without bacterial spores (control); B1, With nutrients and B1 bacterial spores; B2, With nutrients and B2 bacterial spores 


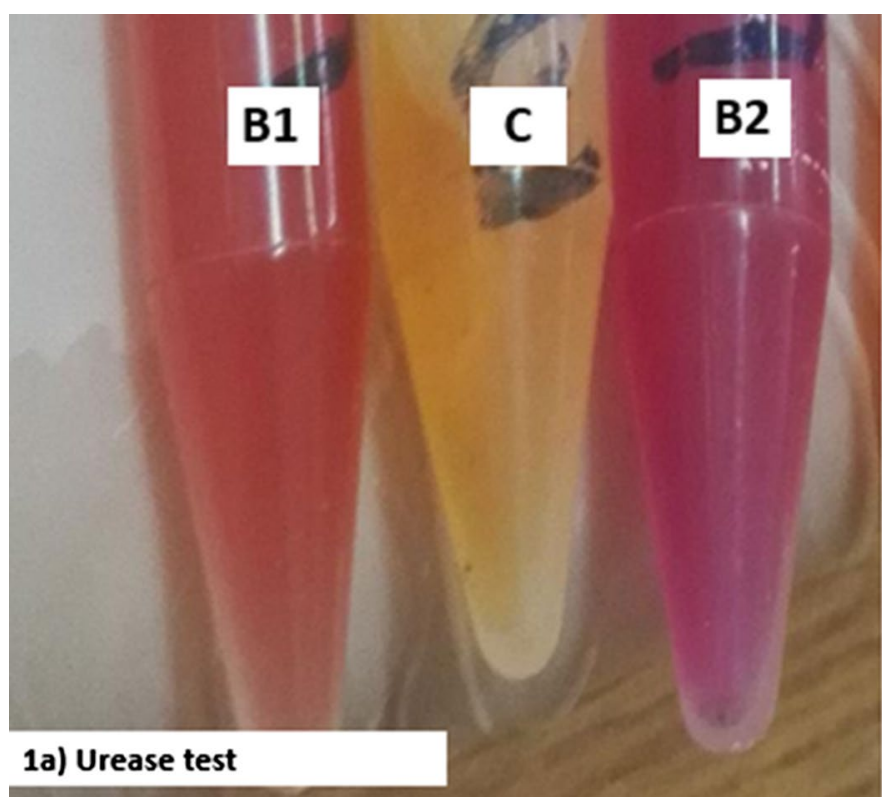

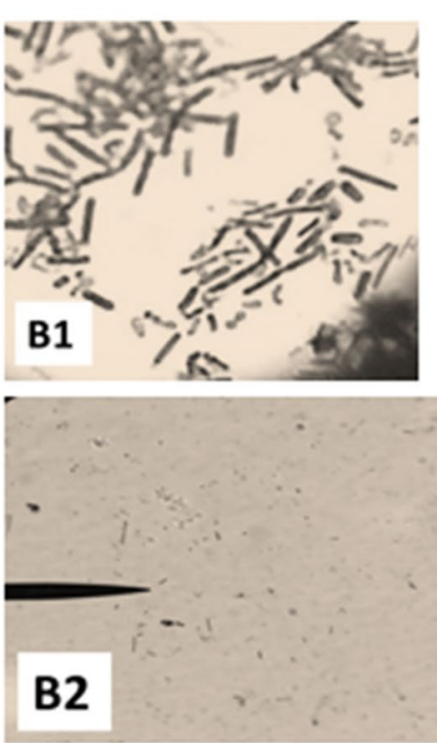

1b) Endospore staining

Fig. 1 a C is the control without bacterial inoculum. B1 and B2 are the bacterial isolates that gave dark pink color after 24 h. Indicating positive urease results using Phenol red as indicator. b Shows that B1 and B2 bacterial isolates are bacilli cells and their endospores appeared as dark black colored spherical dots

Table 2 Urease activity and $\mathrm{CaCO}_{3}$ amount in liquid culture

\begin{tabular}{lcll}
\hline Time $(\mathbf{m i n})$ & $\mathrm{EC}(\mathbf{m S} / \mathbf{m})$ & Time (days) & $\mathrm{CaCO}_{\mathbf{3}}(\mathbf{g})$ \\
\hline B1 & & & \\
0 & $118 \pm 0.29^{\mathrm{f}}$ & 1 & $0.50 \pm 0.03^{\mathrm{e}}$ \\
10 & $120 \pm 0.17^{\mathrm{e}}$ & 3 & $0.79 \pm 0.03^{\mathrm{c}}$ \\
60 & $180.4 \pm 0.12^{\mathrm{d}}$ & 5 & $0.88 \pm 0.01^{\mathrm{bc}}$ \\
100 & $191.5 \pm 0.23^{\mathrm{a}}$ & 7 & $1.18 \pm 0.06^{\mathrm{a}}$ \\
B2 & & & \\
0 & $112 \pm 0.12^{\mathrm{h}}$ & 1 & $0.60 \pm 0.02^{\mathrm{de}}$ \\
10 & $117 \pm 0.23^{\mathrm{g}}$ & 3 & $0.65 \pm 0.03^{\mathrm{d}}$ \\
60 & $182 \pm 0.29^{\mathrm{c}}$ & 5 & $0.81 \pm 0.06^{\mathrm{c}}$ \\
100 & $186 \pm 0.58^{\mathrm{b}}$ & 7 & $0.98 \pm 0.01^{\mathrm{b}}$ \\
\hline
\end{tabular}

$(a, b, \ldots)$ Average in the same column having different subscripts are differ significantly $(P \leq 0.05)$

EC, Electric conductivity; mS/m, millisiemens/meter; B1, Bacillus wiedmannii; B2: Bacillus paramycoides

\subsection{Urease activity}

From the seven bacterial isolates, six of them gave positive urease results. Two isolates (B1 and B2) gave dark pink color after $24 \mathrm{~h}$ as shown in Fig. 1. The other types gave positive results after $48 \mathrm{~h}$. Electric conductivity was measured only for (B1 and B2). B1 exceeded B2 in its activity as recorded in Table 2 . After $100 \mathrm{~min}$, electric conductivity was $191.5 \mathrm{mS} / \mathrm{m}$ and $186 \mathrm{mS} / \mathrm{m}$ for B2.

\section{3 $\mathrm{CaCO}_{3}$ (calcium carbonate) precipitation}

After bacterial inoculation of NB-U/Ca, a white powder immediately appeared in the medium and its intensity increased with incubation period. After 7 days from incubation, $\mathrm{CaCO}_{3}$ precipitants were harvested and weighed. The two bacterial isolates precipitated calcite. The highest amount of calcite $(1.18 \mathrm{~g})$ was precipitated by B. wiedmannii strain FSL W8-0169 and $0.98 \mathrm{~g}$ for B. paramycoides strain MCCC $1 \mathrm{~A} 04098$ as shown in Table 2.

\subsection{Molecular identification}

The Blastx program (BLAST), National Centre for Biotechnology Knowledge, was used to compare the DNA sequences to unknown sequences. It can be clearly seen that the B1 bacteria was included in the genus Bacillus and closely related to the species wiedmannii. It showed the highest sequence similarities with Bacillus wiedmannii strain FSL W8-0169. The strain sequence was submitted to genbank and had accession number MZ434881. B2 bacteria was included in the genus Bacillus and closely related to the species paramycoides. It showed the highest sequence similarities with Bacillus paramycoides strain MCCC 1A04098. The strain sequence was submitted to genbank and had accession number MZ430955. The phylogenetic trees were established and demonstrated in Figs. 2 and 3. 


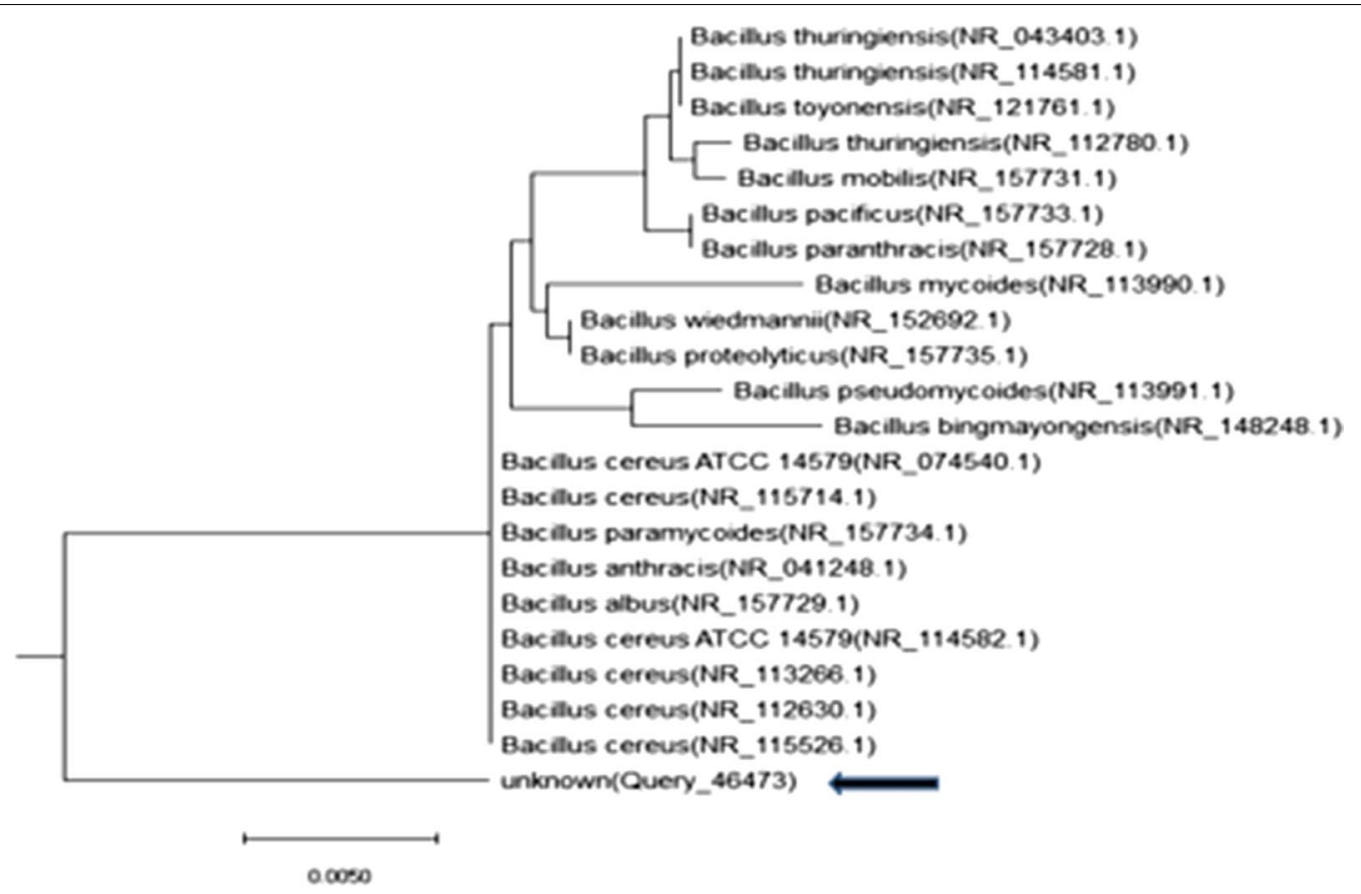

Fig. 2 Phylogenetic dendrogram obtained by distance matrix analysis of 165 rRNA sequences, showing the position of (B1) Bacillus wiedmannii among phylogenetic neighbors

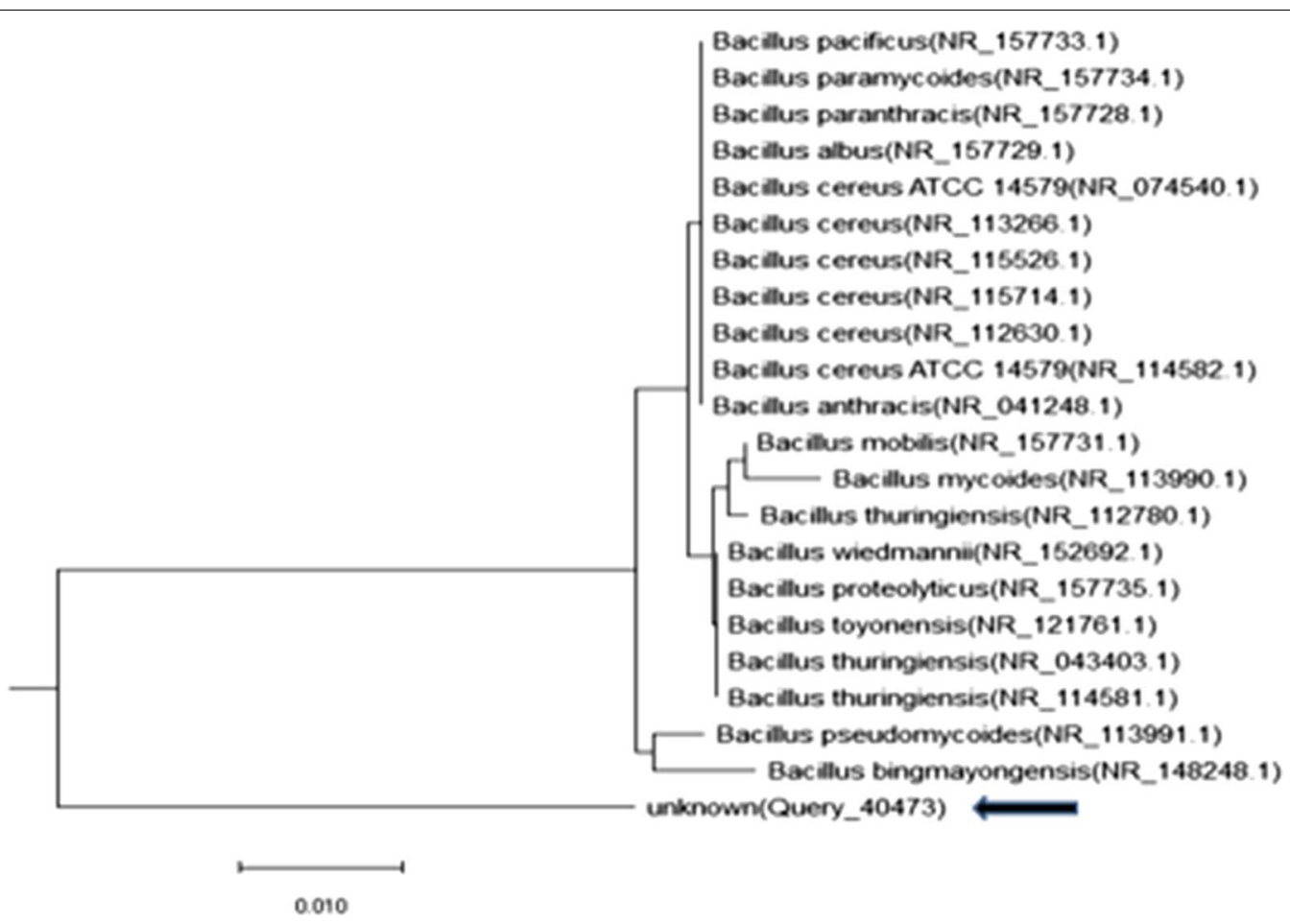

Fig. 3 Phylogenetic dendrogram obtained by distance matrix analysis of 165 rRNA sequences, showing the position of (B2) Bacillus paramycoides among phylogenetic neighbors 


\subsection{Crack healing appearance}

Figure 4 shows the photographs of control and bacterial spore beam specimens' cracks. After 28 and 90 days from water curing, white precipitates were screened in the cracks of bio-concrete specimens. Complete crack repair was recorded in both bacterial beam specimens. In control crack specimens, no observed crack healing was detected. Calcite quantification using EDX-SEM microanalysis showed significant increase percentages in $\mathrm{CaCO}_{3}$ amount and ettringite like structure was observed (Figs. 5, 6, 7).

\subsection{Stalactite deposits}

Figure 4 shows the formation of vertical outgrowths of calcium carbonate that look like stalactite in their appearance (were detected after 90 days from water curing). These outgrowths were observed in bio-concrete specimens but were not observed for control (see also Additional file 1: Figure S2). Ettringite, calcite, and stalactite deposits were screened in bio-concrete specimens and that was the reason for compressive strength improvements.

\subsection{Compressive strength}

The values for the 7,14 , and 28 days of the curing period were determined using three concrete cubes for each period. The values of compressive strength and the percent from 28 days for each period (7, 14, and28 days) were shown in Table 3 . It is seen from the compressive strength data in Table 3 that the bio-based specimens of strength are greater than those of the control sample. The maximum increase in compressive strength at 28 days $(33.7 \mathrm{MPa})$ was obtained for concrete specimens inoculated with $B$. wiedmannii strain FSL W8-0169 and $28.5 \mathrm{MPa}$ for B. paramycoides strain MCCC 1A04098, the strength of control was $23 \mathrm{MPa}$ indicating that there were strength improvements by $46.52 \%$ and $23.91 \%$, respectively more than control.
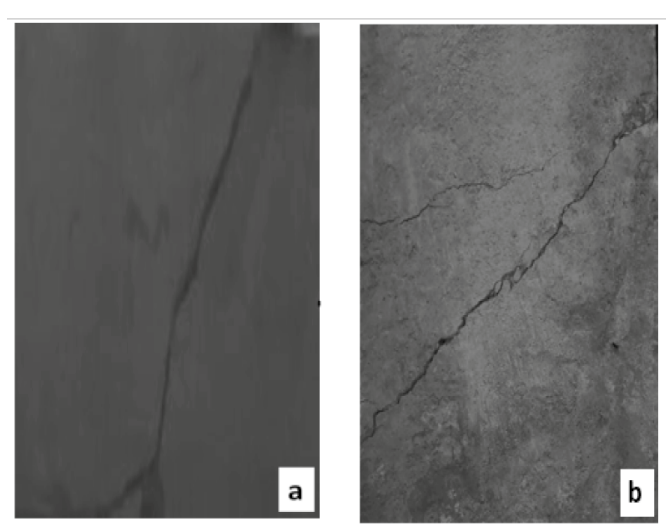

1: Photo images of control (concrete with bionutrients and without bacterial spores) show unhealed cracks; a) after 28 days from water curing and b) after 90 days from water curing.

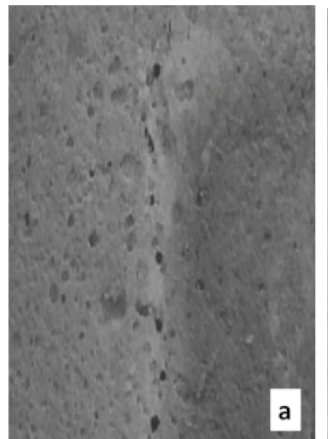

3: Photo images show the bacterial isolate B2 (Bacillus paramycoides) bio-healed cracks; a) Shows the complete bio-healing in the cracks after 28 daysfrom water curing and b) Shows the stalactite deposits in the bio-healed cracksafter 90 days from water curing.

Fig. 4 Shows the crack filling with calcite using both bacterial types (2\&3) and no calcite precipitation in control specimens (1) 


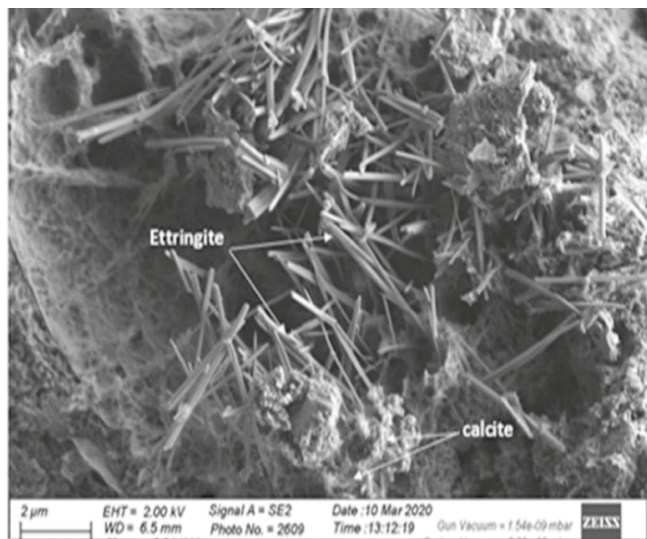

1-SEM micro-image shows calcite and ettringite precipitation in bio-concrete cracks

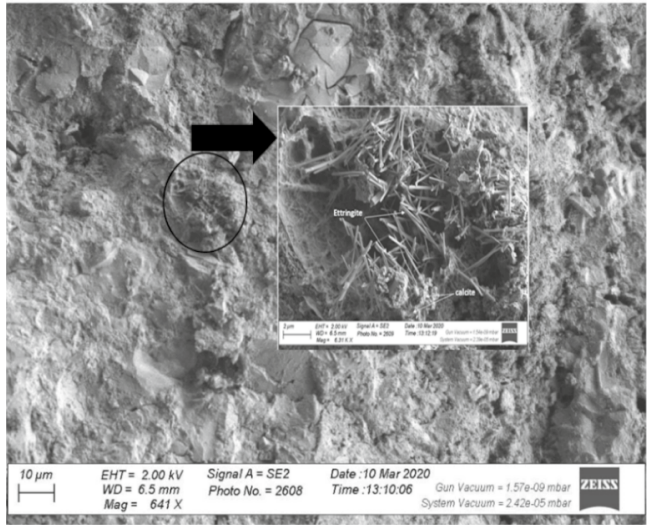

3-SEM micro-image in B1 (Bacillus wiedmannii) bioconcrete specimen shows tightly packed appearance with calcite precipitation.

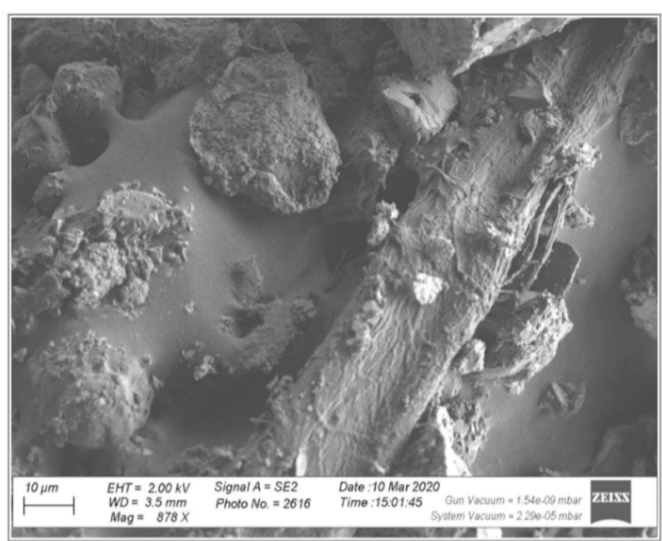

2- SEM micro-image in B2 (Bacillus paramycoides) bioconcrete specimen shows calcite precipitation

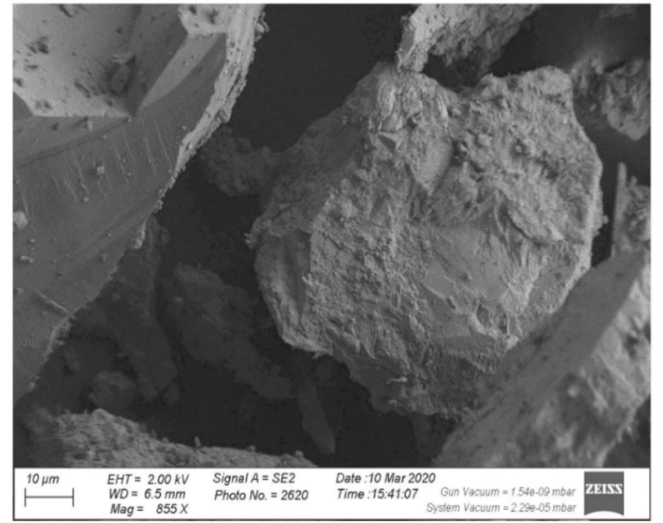

4- SEM micro-image in control concrete specimen shows loose appearance with no calcite.

Fig. 5 SEM micro-images shows calcite and ettringite in bio-concrete specimens

\section{Discussion}

Bacteria can withstand harsh mechanical- and chemical-induced stresses during the mixing of concrete by their capability for endospore formation [19] and these endospores can live for up to 200 years [20]. As cracks occur, water will ingress into them causing the activation of the incorporated bacterial spores, and by microbial nutrients metabolism, $\mathrm{CaCO}_{3}$ is formed by germination of spores into vegetative cells [21]. Because of their ability to hydrolyze urea into ammonia and carbonate, both bacterial isolates may precipitate $\mathrm{CaCO}_{3}$. Ammonia causes a rise in $\mathrm{pH}$, which creates a favorable climate for calcium carbonate precipitation. $\mathrm{CaCO}_{3}$ precipitates when carbonate combines with calcium in a mixture [3]. The improvement in compressive strength caused by the inclusion of bacteria is likely due to the deposition of calcite on the surfaces of the microorganism cells and in the concrete pores [1]. The insignificant increase in the compressive strength of control specimens of media alone without spore inoculation shows that the medium nutrients do not have any effective impact on strength improvement. Chahal et al. [22]; Al-Thawadi and Cord-Ruwisch [23] showed the improvement in compressive strength through the bacterial based materials that is possibly due to the deposition of calcite on the surfaces of the microorganism cells and through the pores of the concrete. The bio-based concrete showed calcite precipitation due to presence of calcite-precipitating bacteria which is the reason for higher strength of bio-based concrete specimens. B. wiedmannii precipitated high calcite amount and gave strength improvements than $B$. paramycoides. These results confirm that the strong capability for $\mathrm{CaCO}_{3}$ precipitation is related with bacterial ureolytic activity. The capability of ureolytic activity varies according to bacterial type and that is confirmed by Krishnapriya et al. [1] who showed B. licheniformis BSKNAU, B. megaterium 


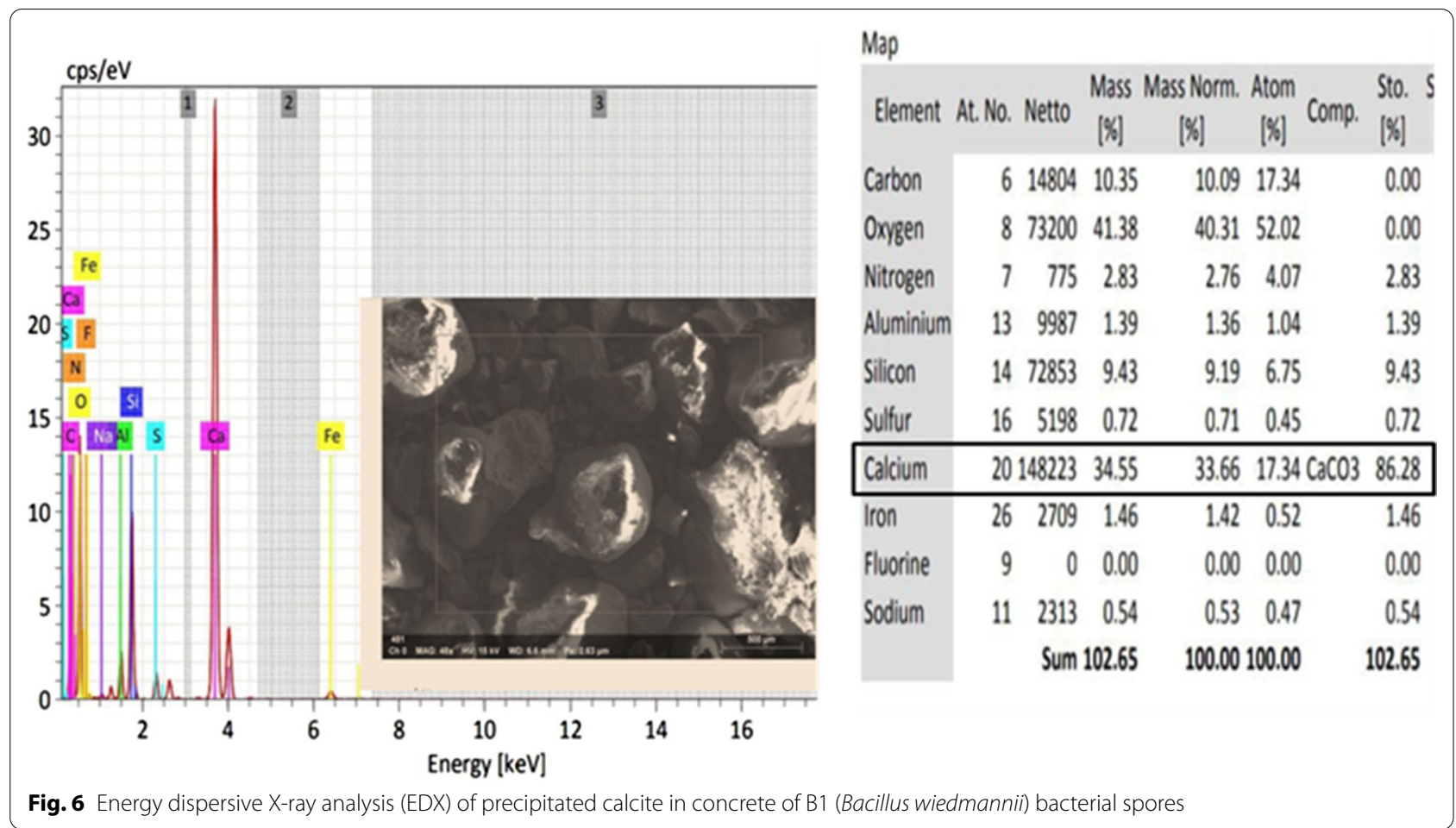

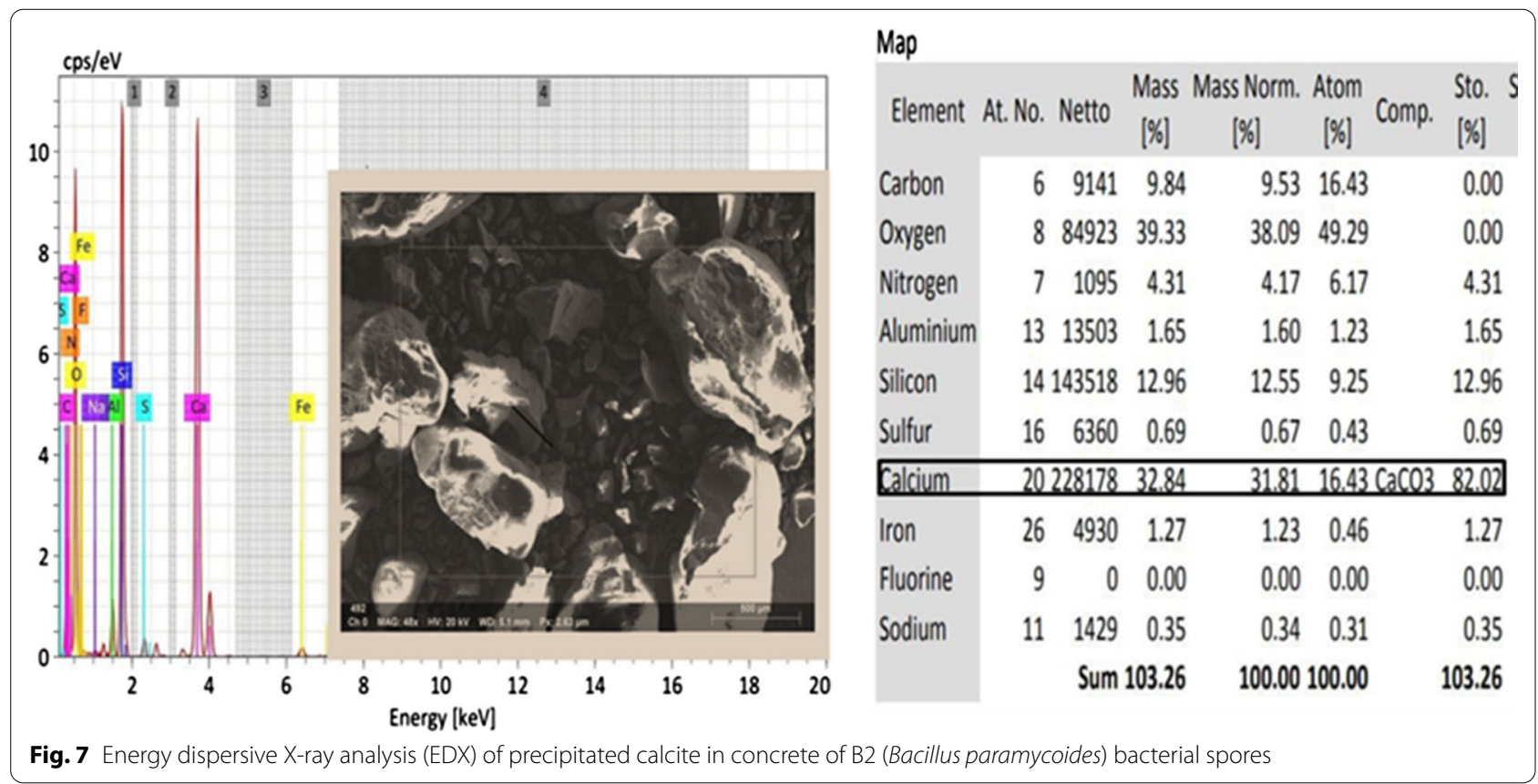

BSKAU, B. flexus BSKNAU, and B. megaterium MTCC 1684 varied in their response toward calcite precipitation. SEM micrographs showed presence of $\mathrm{CaCO}_{3}$ crystals in bacterial specimens and these results are in agreement with Chahal et al. [24], Fujita et al. [25] who also illustrated that specific calcite crystals were screened in the SEM analysis of bio-based concrete and the matrix of untreated specimens seemed to be amorphous, exhibiting no apparent growth of crystals. 
Table 3 Ratio of the compressive strength for each period (7 \& $14 \& 28$ days)

\begin{tabular}{lclc}
\hline $\begin{array}{l}\text { Type of } \\
\text { concrete }\end{array}$ & Period (days) & $\begin{array}{l}\text { Compressive } \\
\text { strength (MPa) }\end{array}$ & $\begin{array}{l}\text { (\% form 28 days } \\
\text { for each type) }\end{array}$ \\
\hline C & 7 & $16.2 \pm 0.58^{\mathrm{f}}$ & 70 \\
& 14 & $19.8 \pm 0.58^{\mathrm{e}}$ & 86 \\
& 28 & $23.0 \pm 0.58^{\mathrm{d}}$ & 100 \\
B1 & 7 & $20.1 \pm 0.58^{\mathrm{e}}$ & 60 \\
& 14 & $26.5 \pm 0.58^{\mathrm{c}}$ & 78 \\
& 28 & $33.7 \pm 0.58^{\mathrm{a}}$ & 100 \\
B2 & 7 & $18.5 \pm 0.58^{\mathrm{e}}$ & 65 \\
& 14 & $22.3 \pm 0.58^{\mathrm{d}}$ & 78 \\
& 28 & $28.5 \pm 0.58^{\mathrm{b}}$ & 100 \\
\hline
\end{tabular}

$(a, b, \ldots)$ Average in the same column having different subscripts are differ significantly $(P \leq 0.05)$

\section{Conclusions}

$B$. wiedmannii and B. paramycoides can act as biohealing agents as they were examined for calcite-precipitating in concrete to fill the pre-cracked specimens and the improvement in compressive strength was also illustrated. Ettringite, calcite, and stalactite deposits formation were illustrated. From our findings, the two bacterial species can be included in water buildings and those are built on the shores of the seas and rivers to protect them against cracks they suffer from. More studies related to the healing effect of new bacterial species on slabs and columns are recommended for future work.

\section{Abbreviations}

ANA: Alkaline nutrient agar; B1: Bacillus wiedmannii; B2: Bacillus paramycoides; EC: Electric conductivity; EDX-SEM: Scanning electron microscopy (SEM) with energy dispersive X-ray analysis (EDX); MICP: Microbial-induced $\mathrm{CaCO}_{3}$ precipitation; mS/m: Millisiemens/meter; NB-U/Ca: Nutrient broth implemented with $2 \%$ urea and $\mathrm{CaCl}_{2}$.

\section{Supplementary Information}

The online version contains supplementary material available at https://doi. org/10.1186/s43088-021-00142-7.

Additional file 1. Figure 1: (a) urease test of the alkali-tolerant bacterial isolates (B1, B, 10, 5, 2 and B2), and (b) shows the presence of endospores for all the bacterial isolates. B1: Bacillus wiedmannii. B2: Bacillus paramycoides. Figure 2: (a) Control concrete, (b) bio-concrete specimen of Bacillus wiedmannii after 28 days water curing, (c) bioconcrete specimen of Bacillus wiedmannii after 90 days, (d) bio-concrete specimen of Bacillus paramycoides after 28 days, and e) bio-concrete specimen of Bacillus paramycoides after 90 days.

\section{Acknowledgements}

Not applicable.

\section{Authors' contributions}

AMR and AE conceived, designed, and coordinated the study. GM and AMR carried out the experimental studies. AMR and AE wrote, organized, and revised the manuscript. All authors have read and approved the final manuscript.

Funding

Not applicable.

Availability of data and materials

All data generated or analyzed during this study are included in this published article.

\section{Declarations}

Ethics approval and consent to participate

Not applicable.

\section{Consent for publication}

Not applicable.

\section{Competing interests}

No potential conflict of interest was reported by the authors.

\section{Author details}

${ }^{1}$ Civil Engineering Department, Faculty of Engineering, Fayoum University, Fayoum, Egypt. ${ }^{2}$ Botany Department, Faculty of Science, Fayoum University, Fayoum, Egypt.

Received: 10 April 2021 Accepted: 22 August 2021

Published online: 09 September 2021

\section{References}

1. Krishnapriya S, Venkatesh Babu DL, Prince AG (2015) Isolation and identification of bacteria to improve the strength of concrete. Microbiol Res 174:48-55. https://doi.org/10.1016/j.micres.2015.03.009

2. Zoheir AE, Hammad IA, Talkhan FN (2013) Urease activity and induction of calcium carbonate precipitation by Sporosarcina pasteurii NCIMB 8841. J Appl Sci Res 9(3):1525-1533

3. Stocks-Fischer S, Galinat JK, Bang SS (1999) Microbiological precipitation of $\mathrm{CaCO}_{3}$. Soil Biol Biochem 31(11):1563-1571. https://doi.org/10.1016/ S0038-0717(99)00082-6

4. Wu M, Hu X, Zhang Q, Xue D, Zhao Y (2019) Growth environment optimization for inducing bacterial mineralization and its application in concrete healing. Constr Build Mater 209:631-643. https://doi.org/10. 1016/j.conbuildmat.2019.03.181

5. Erşan YÇ, Da Silva FB, Boon N, Verstraete W, De Belie N (2015) Screening of bacteria and concrete compatible protection materials. Constr Build Mater 88:196-203. https://doi.org/10.1016/j.conbuildmat.2015.04.027

6. Ghosh P, Mandal S, Chattopadhyay BD, Pal S (2005) Use of microorganism to improve the strength of cement mortar. Cem Concr Res 35(10):19801983. https://doi.org/10.1016/j.cemconres.2005.03.005

7. Achal V, Mukherjee A, Basu PC, Reddy MS (2009) Lactose mother liquor as an alternative nutrient source for microbial concrete production by Sporosarcina pasteurii. J Ind Microbiol Biotechnol 36(3):433-438. https:// doi.org/10.1007/s10295-008-0514-7

8. Castanier S, Le Métayer-Levrel G, Perthuisot JP (1999) Ca-carbonates precipitation and limestone genesis - the microbiogeologist point of view. Sediment Geol 126(1-4):9-23. https://doi.org/10.1016/S0037-0738(99) 00028-7

9. Siddique R, Chahal NK (2011) Effect of ureolytic bacteria on concrete properties. Constr Build Mater 25(10):3791-3801. https://doi.org/10. 1016/j.conbuildmat.2011.04.010

10. Charpe AU, Bhutange SP, Latkar MV, Chakrabarti T (2020) Studies on Biocementation of Mortar and Identification of Causative Bacteria. Arab J Sci Eng. https://doi.org/10.1007/s13369-020-05040-1

11. Whiffin VS (2004) Microbial $\mathrm{CaCO}_{3}$ precipitation for the production of Biocement. PhD Thesis. Murdoch University, Western Australia 
12. Ishak WMFW, Jamek $S$, Jalanni NA, Jamaludin NFM (2011) Isolation and Identification of Bacteria from Activated Sludge and Compost for Municipal Solid Waste Treatment System. Int Conf Biol Environ Chem 24:450-454

13. Christensen WB (1946) Urea decomposition as a means of differentiating Proteus and paracolon cultures from each other and from Salmonella and Shigella. J Bacteriol 52:461-467

14. Omoregie Al, Khoshdelnezamiha G, Senian N, Ong DEL, Nissom PM (2017) Experimental optimisation of various cultural conditions on urease activity for isolated Sporosarcina pasteurii strains and evaluation of their biocement potentials. Ecol Eng 109(September):65-75. https://doi.org/ 10.1016/j.ecoleng.2017.09.012

15. Hussey MA (2013) Endospore stain protocol. Am Soc Microbiol 2007(September):1-11

16. Sambrook J, Russell D (2001) Molecular cloning: a laboratory manual, 3rd edn. Cold Spring Harbor Laboratory Press, Cold Spring Harbor

17. SPSS (2015) Statistical Package For Social Science (for Windows). Release 23 Copyright (C), SPSS Inc., Chicago, USA

18. Duncan DB (1955) Multiple range and multiple F tests. Biometrics 11:1-42

19. Stanaszek-Tomal E (2020) Bacterial concrete as a sustainable building material? Sustainability. https://doi.org/10.3390/su12020696

20. Seifan M, Samani AK, Berenjian A (2016) Induced calcium carbonate precipitation using Bacillus species. Appl Microbiol Biotechnol 100(23):98959906. https://doi.org/10.1007/s00253-016-7701-7
21. Schreiberová H, Bílý P, Fládr J, Šeps K, Chylík R, Trtík T (2019) Impact of the self-healing agent composition on material characteristics of bio-based self-healing concrete. Case Stud Constr Mater. https://doi.org/10.1016/j. cscm.2019.e00250

22. Chahal N, Siddique R, Rajor A (2012) Influence of bacteria on the compressive strength, water absorption and rapid chloride permeability of fly ash concrete. Constr Build Mater 28(1):351-356. https://doi.org/10.1016/j. conbuildmat.2011.07.042

23. Al-Thawadi S, Cord-Ruwisch R (2012) Calcium carbonate crystals formation by ureolytic bacteria isolated from Australian soil and sludge. J Adv Sci Eng Res 2(Ma 2014):12-26

24. Chahal N, Rajor A, Siddique R (2011) Calcium carbonate precipitation by different bacterial strains. Afr J Biotechnol 10(42):8359-8372. https://doi org/10.5897/ajb11.345

25. Fujita Y, Ferris FG, Lawson RD, Colwell FS, Smith RW (2000) Calcium carbonate precipitation by ureolytic subsurface bacteria. Geomicrobiol J 17(4):305-318. https://doi.org/10.1080/01490450050193360

\section{Publisher's Note}

Springer Nature remains neutral with regard to jurisdictional claims in published maps and institutional affiliations.

\section{Submit your manuscript to a SpringerOpen ${ }^{\circ}$ journal and benefit from:}

- Convenient online submission

- Rigorous peer review

- Open access: articles freely available online

- High visibility within the field

- Retaining the copyright to your article

Submit your next manuscript at $\boldsymbol{\nabla}$ springeropen.com 